\title{
Dementia and Geriatric Cognitive Disorders
}

Editorial Board

L. Amaducci, Florence M.J. Ball, Portland, Oreg.

K. Beyreuther, Heidelberg

A. Brun, Lund

S.H. Ferris, New York, N.Y.

C.G. Gottfries, Molndal

L. Gustafson, Lund

I. Hanin, Maywood, 111.

K. Hasegawa, Kawasaki

Sttpefti, Harlow

S. Hirai, Tokyo

P.G. Ince, Newcastle upon Tyne

F. Javoy-Agid, Paris

A.D. Korczyn, Tel Aviv 
M.J. de Leon, New York, N.Y.

C.L. Masters, Melbourne

R. Mayeux, New York, N.Y.

D.L. Murphy, Bethesda, Md.

E.K. Perry, Newcastle upon Tyne

J.W. Pettegrew, Pittsburgh, Pa.

D. Price, Baltimore, Md.

J. Rogers, Sun City, Ariz.

A.D. Roses, Durham, N.C.

M. Roth, Cambridge

Y, Sakaki, Fukuokashi

H.M. Wisniewski, Staten Island, N.Y.

M. Yoshida, Tochigi 


\section{Contents Vol. 8, 1997}

Dementia

and Geriatric CognitiveDisorders

No. 1 
Original Research Articles

1 Trk Neurotrophin Receptors in Cholinergic Neurons of Patients with Alzheimer's Disease

Boissiere, F.; Hunot, S.; Faucheux, B. (Paris); Hersh, L.B. (Lexington, Ky.); Agid, Y.; Hirsch, EG(Paris)

9 A Multicenter Randomized Double-Blind Study on the Efficacy and Safety of Nicergoline in Patients with Multi-lnfarct Dementia

Hermann, W.M.; Stephan, K.; Gaede, K.(Berlin); Apeceche, M. (Munchen) 18 Age vs. Aging in the Pathogenesis of Senile Dementia of the

Alzheimer Type: Electrophysiological Evidence

Politoff, A.L.; Monson, N. (Fargo, N. Dak.) 26 Intracerebroventricular Administration of GM1 Ganglioside to

Presenile Alzheimer Patients

Augustinsson, L.-E.; Blennow, K.; Blomstrand, C; Brane, G.; Ekman, R.;

Fredman, P.; Kartsson, I, (Gfiteborg); Kihlgren, M. (Orebro); Lehraann, W.;

Lekman, A.; Mansson, J.-E.; Ramstrom, I.; Wallin, A.; Wikkelso, C;

Gottfries, C.-G.; Svennerholm, L. (Gbteborg)

34 Neurochemical Differences in the CSF between Binswanger's and Alzheimer's Disease

Strittmatter, M.; Hamann, G.F.; Grauer, M.T. (Homburg); Cramer, H. (Freiburg); Scbimrigk, K. (Homburg)

43 In vitro Effect of Ginkgo biloba Extract (EGb 761) on the Activity of Presynaptic Cholinergic Nerve Terminals in Rat Hippocampus KriStofikova, Z:; KJaschka, J. (Prague)

49 Tone Duration Discrimination in Demented, Memory-Impaired,

and Healthy Elderly

Hellstrom, A.; Almkvist, O. (Stockholm)

55 Non-Alzheimer Dementia with Status spongiosus and

Neuronal Cell Loss Showing Unusual Perineuronal Structures and Point Mutation at 129 Codon of Prion Protein

Hayashi, M. (Toyama/Kanazawa); Kobayashi, K.; Ishida, G; Aoki, T.; Muramori, F. (Kanazawa); Miyazu, K. (Takaoka); Jibiki, I.; Koshino, Y.;

Ya maguch i, N. (Kanazawa)

Letter to the Editor

60 Screening for Mutation of the Presenilin 2 Gene in Alzheimer's Disease

Isoe, K.; Urakami, K.; Wakutani, Y.; Yong, Ji.; Adachi, Y.; Nakashima, K. (Yonago) 
Brain Imaging and Psychogeriatric Services in Geriatric Psychiatry 23rd Symposium of the European Association of Geriatric Psychiatry, Lund, October 6-7, 1995 Guest Editors: Gustafson, L,; Risberg, J. (Lund)

65 Preface

Gustafson, L.; Risberg, J. (Lund)

Brain Imaging

66 History of Brain Imaging In Psychiatry Ingvar, D.H. (Lund)

73 Seeing Visual Hallucinations with Functional Magnetic Resonance Imaging

Howard, R.; David, A.; Woodruff, P.; Mellers, J.; Wright, I.; Brammer, M.; Bullmore, E.; Williams, S. (London)

78 Imaging of Nicotinic and Muscarinic Receptors in Alzheimer's Disease: Effect of Tacrine Treatment

Nordberg, A. (Huddinge); Lundqvist, H.; Hartvig, P.; Andersson, J.; Johansson, M. (Uppsala); Hellstrom-Lindahl, E. (Huddinge); Langstrotn, B. (Uppsala)

85 The Use of SPECT in a Multidisciplinary Memory Clinic

Pasquier, F.; Lavenu, I.; Lebert, F.; Jacob, B.; Steinling, M.; Petit, H. (Lille)

92 Regional Cerebral Blood Flow Measurements in the Clinical Evaluation of Demented Patients

Risberg, J.; Gustafson, L. (Lund)

98 Reduction of Regional Cerebral Blood Flow and Cognitive Impairment in Patients with Alzheimer's Disease: Evaluation of an Observer-Independent Analytic Approach

Hirsch, Ch.; Bartenstein, P. (Munich); Minoshima, S. (Ann Arbor, Mich.); Mosch, D.; Willoch, F.; Buch, K.; Schad, D.; Schwaiger, M.; Kurz, A. (Munich)

105 Functional Imaging of the Frontal Lobes in Organic Dementia.

Regional Cerebral Blood Flow Findings in Normals, in Patients with Frontotemporal Dementia and in Patients with Alzheimer's Disease, Performing a Word

Fluency Test Warkentin, S.; Passant, U. (Lund) 110 Electroencephalography as a Diagnostic Tool in Dementia Rosdn, I. (Lund)

117 New Approaches to Imaging Based on Effects of Neurotoxins

Francis, P.T. (London); Chessetl, IJ*. (Cambridge); Bowen, D.M. (London)

123 Neuropathological Brain Mapping

Bran, A.; Englund, E. (Lund)

Psychogeriatric Services

128 Project for the Development of an Ambulatory and Semi-Ambulatory Community Center for the Third Age Tataru, N. (Oradea)

132 Services for Older People with Mental Health Problems: Inequalities and Strategies to Help the 'Have-Nots'

Jolley, D. (Manchester)

136 Group-Living Care: An Alternative for the Demented Elderly

Annerstedt, L. (Lund)

143 Psychogeriatric Organization in the Medico-Social Network: The Experience of the Canton of Vaud, Switzerland

Wertheimer, J. (Lausanne)

146 Author Index 146 Subject Index

\section{KARGER}

E-Mail karger@karger.chFax+4161 3061234 
C 1997 S. Karger AG, Basel

The list of contents is available at: http://wwwJcarger.ch/joumals/dem/demcontJitni 
No. 3 


\section{Original Research Articles}

147 Weight, Blood Pressure, Osmolarity, and Glucose Levels across Various Stages of Alzheimer's Disease and Vascular Dementia Hogan, D.B.; Ebly, E.M. (Calgary); Rockwood, K. (Halifax)

152 Effect of Repetition and Inspection Times on Picture Recall in Patients with Dementia of Alzheimer Type Heun, R.; Burkart, M.;Benkert, O. (Mainz) 157 Subplal Amyloid Plaques in the Cerebellum in a Case of Alzheimer's Disease

Takamatsu, J.; Kimura, T. (Kumamoto); Kondo, A. (Saga); Iwatsubo, T. (Tokyo)

163 Vascular Variant of Alzheimer's Disease Characterized by Severe Plaque-Like B Protein Angiopathy

Yamada, M.; Itoh, Y.; Suematsu, N.; Otomo, E.; Matsushita, M. (Tokyo)

169 Neuron-Specific Enolase, S-100 Protein, Myelin Basic Protein and Lactate in CSF in Dementia

Nooijen, P.T.G.A.5 Schoonderwaldt, H.C.; Wevers, R.A.; Hommes, O.R.; Lamers, K.J.B. (Nijmegen)

174 Gangliosides and Sulfatide in Cerebrospinal Fluid in Leukoaraiosis

Tarvonen-Schroder, S. (Turku); Blennow, Kl; Lekman, A.; Fredman, P. (Goteborg); Raiha, I.; Sourander, L. (Turku)

180 Postural Hypotension and EEG Variables Predict Cognitive Decline: Results from a 5-Year Follow-Up of Healthy Elderly Women

Elmstahl, S.; Rosen, I. (Malmo) 188 Drug Treatment in Lewy Body Dementia

Geroldi, C.; Frisoruj G.B.; Bianchetti, A.; Trabucchi, M. (BrescSft

198 Diagnosing Alzheimer's Disease in Community-Dwelling Elderly: A Comparison of EEG and MRl

Strijers, R.L.M.; Scheltens, Ph.; Jonkman, E.J.; de Rijke, W.; Hooijer, Ch.; Jonker, C. (Amsterdam) 
Review

203 The Cerebellum in Alzheimer's Disease

Lamer, A.J. (Cambridge)

Original Research Articles

210 Procedural Memory in Patients with Mild Alzheimer's Disease

Hirono, N.; Mori, R; Ikejun^Y.; Imamura, T.; Shimomura, T.; Ikeda, M.; Yamashita, H.; Takatsuki, Y,; Tokimasa, A. (Himeji); Yamadori, A. (Sendai)

217 Progressive Formation of Neuritic Plaques and Neurofibrillary Tangles Is Exponentially Related to Age and Neuronal Size.

A Morphometric $\mathrm{Stj}^{\wedge} \mathrm{y}$ of Three Geographically DistincBSeries of Aging People

Dani, S.U. (Hannover); Jftttella, J.E.H. (Belo Horizonte); Boehme, A.; Hori, A.; Schneider, B. (Hannover)

228 The Disturbances of Object Vision and Spatial Vision in Alzheimer's Disease

Fujimori, M.; Imamura, T.; Yamashita, H.; Hirono, N.; Mori, E. (Himejij

232 Somatostatin and Neuropeptide Y in Cerebrospinal Fluid: Correlations with Severity of Disease and Clinical Signs in Alzheimer's Disease and Frontotemporal Dementia

Minthon, L.; Edvinsson, L.; Gustafson, L. (Lund)

240 Apolipoprotein-E Genotyping in Alzheimer's Disease and

Frontotemporal Dementia

Gustafson, L.; Abrahamson, M.; Grubb, A.; Nilsson, K.; Fex, G. (Lund) 244 Distinguishing between Patients with Depression or Very Mild

Alzheimer'sDisease Using the Delayed-Word-Recall Test

Coen, R.F.; Kirby, M.; Swanwick, G.R.J.; Maguire, C.P.; Walsh, J.B.;

Coakley, D.; O'Neill, D.; Lawlor, B.A. (Dublin)

248 Staging of Alzheimer-Type Pathology: An Interrater-lntrarater Study

Nagy, Zs. (Oxford); Vatter-Bitffier, B.; Braak, H.; Braak, R; Yilmazer, D.M.; Schultz, C; Hanke, J. (Frankfurt/M.)

\section{Case Report}

252 The Vascular Dementia of Fabry's Disease

Mendez, M.F.; Stanley, Th.M.; Medel, N.M.; Li, 2.; Tedesco, D.T. ^^-os Angeles, Calif.)

Letter to the Editor

258 Senile Dementia and Apolipoprotein E4

McConathy, W.; Lacko, A. (Fort Worth, Tex.); Kalman, J. (Szeged) 
Dement Geriatr Cogn Disord Vol. 8,1997 


\section{Contents}


No. 5 


\section{Original Research Articles}

259 Regional Brain Distribution and Binding of the Muscarinic Receptor Agonist CI-979 Studied by Positron Emission Tomography in the Monkey Hartvig, P.; Torstenson, R.; Bjurling, P.; Fasth, KJ.; Langstrom, B. (Uppsala); Nordberg, A. (Huddinge)

267 Interrelationship between Beta-Amyloid Deposition and Complement-Activated Oligodendroglia Yamada, T.; Tsuboi, Y.; Takahasbi, M. (Chiba) 273 Alzheimer's Disease Assessment Scale: The Validation of the Scale in Greece in Elderly Demented Patients and Normal Subjects Tsolaki, M.; Fountoulakis, K.; Nakopoulou, E.; Kazis, A. (Thessaloniki); Mohs,R.C. (Bronx, N.Y.)

281 Effect of Normal Aging and of Alzheimer's Disease on Episodic Memory

Le Moal, S.; Reymann, J.M.; Thomas, V.; Cattenoz, C; Lieury, A.; AUain, H. (Rennes)

288 Presence of the Apolipoprotein E Type e4 Allele Is Not Associated with Neurofibrillary Pathology or Biochemical Changes to Tau Protein Mukaetova-Ladinska, E.B.; Harrington, C.R.; Roth, M.; Wischik, CM. (Cambridge)

296 Neurodegeneration and Gliosis in Transgenic Mice

Overexpressing a Carboxy-Terminal Fragment of Alzheimer Amyloid-p Protein Precursor

Sato, M. (Saitama/Kanagawa); Kawarabayashi, T.; Shoji, M. (Gunma); Kobayashi, T.; Tada, N. (Saitama); Matsubara, E.; Hirai, S. (Gunma)

308 Excitatory Pattern of Gamma-Interferon on Natural Killer Cell Activity in Senile Dementia of the Alzheimer Type

Solerte, S.B.; Fioravanti, M.; Severgnini, S.; Pezza, N.; Locatelli, M.; Cerutti, N.; Terenzi, F.; Ferrari, E. (Pavia)

314 The Effects of Dementia in German Acute Care Hospitals

Dinkel, R.H. (Bamberg); Lebok, U.H. (Munich)

320 A 12-Month, Randomized, Placebo-Controlled Trial of Propentofylline (HWA 285) in Patients with Dementia According to DSM lll-R

Marcusson, J.; Rother, M.; Kittner, B.; Rossner, M.; Smith, R.J.; Babic, T.; Folnegovic-Smalc, V.; Moller, H.J.; Labs, K.H. on behalf of the European Propentofylline Study Group 
329 Amygdala-Hippocampal Atrophy and Memory Performance in Dementia of Alzheimer Type

Heun, R. (Mainz/Bonn); Mazanek, M.; Atzor, K.-R.; Tintera, J.; Gawehn, J.; Burkart, M.; Gansicke, M. (Mainz); Falkai, P. (Bonn); Stoeter, P. (Mainz)

337 Monomeric and Polymeric Forms of Alpha-1 Antichymotrypsin in Sera from Patients with Probable Late Onset Alzheimer's Disease

Licastro, F.; Sirri, V.; Trere, D.; Davis, L.J. (Bologna)

343 Global Dimensional Complexity of Multichannel EEG in Mild Alzheimer's Disease and Age-Matched Cohorts

Yagyu, T. (ZUrich/Osaka); Wackennann, J. (Prague); Shigeta, M. (Stockholm/Tokyo); Jelic, V. (Stockholm); Kinoshita, T. (Osaka); Kochi, K. (Zurich); Julin, P.; Almkvist. O.; Wahlund, L.-0. (Stockholm); Kondakor, I.; Lehmann, D. (ZUrich)

348 A SPECT Imaging Study of MRI White Matter Hyperintensity in Patients with Degenerative Dementia

Ott, B.R.; Faberman, R.S.; Noto, R.B.; Rogg, J.M.; Hough, T.J.; Tung, G.A.; Spencer, P-K. (Providence, R.I.)

355 Early-Stage Alzheimer's Disease and Multiple Subcortical Infarction with Mild Cognitive Impairment: Neuropsychological Comparison Using an Easily Applicable Test Battery

Tei, H. (Tokyo/Toda); Miyazaki, A.; Iwata, M.; Osawa, M.; Nagata, Y. (Tokyo); Maruyama, S. (Toda)

359 Assessment of Ambulatory Behavior in Nursing Home Residents Who Pace or Wander: A Comparison of Four Commercially Available Devices Cohen-Mansfield, J. (Rockville, Md.); Werner, P. (Tel Aviv); Culpepper, W.J.; Wolfson, M.; Bickel, E. (Rockville, Md.)

366 Comparative Effects of Ageing and Dementia of the Alzheimer Type on Orientation of Visual Attention Wright, M.; Geffen, G.; Geflen, L. (Brisbane)

376 Episodic Memory Functioning in Population-Based Samples of Very Old Adults with Alzheimer's Disease and Vascular Dementia

Hassing, L. (Goteborg): Backman, L. (GSteborg/Stockholm)

384 Borrelia burgdorferi-Sevopositive Chronic

Encephalomyelopathy: Lyme Neuroborreliosis?

AnAutopsied Report

Kobayashi, K.; Mizukoshi, C; Aoki, T.; Muramori, F.; Hayashi, M.;

Miyazu, K.; Koshino, Y.; Ohta, M.; Nakanishi, I.; Yamaguchi, N. (Kanazawa)

391 Author Index Vol. 8,1997

392 Subject Index Vol. 8,1997

Suppl. 1

Nicergoline in Dementias: From Pharmacology to Clinical Application

Satellite Symposium held during the 4th International Nice/Springfield Symposium on Advances in Alzheimer Therapy, Nice, France, April 11,1996

Guest Editor Amaducci, L. (Florence) 
Dement GeriatrCogn Disord Vol. 8,1997 
